\title{
DETAILED STRATIFICATION AND CORRELATION OF FORAMINIFERA PALEOGENE DEPOSITS OF UKRAINE
}

\author{
N.V. Maslun ${ }^{1}$, L.G. Mintuzova², S.R. Hnylko ${ }^{3}$ \\ (Recommended by academician of NAS of Ukraine P.F. Gozhik) \\ ${ }^{1}$ Institute of Geological Sciences of NAS of Ukraine, Kyiv, Ukraine, E-mail: ivanik_m@ukr.net \\ Candidate of geological-mineralogical sciences, leading research scientist. \\ ${ }^{2}$ Lviv branch of UkrNDHRI, Lviv, Ukraine. \\ Candidate of geological-mineralogical sciences, senior research scientist. \\ ${ }^{3}$ Institute of Geology and Geochemistry of Combustible Minerals of NAS of Ukraine, Lviv, Ukraine, \\ E-mail:s.hnylko@mail.ru \\ Junior research scientist.
}

Zonal distribution of small foraminifera from the Paleogene deposits of Tethys and «boreal» North Atlantic Provinces of Ukraine is showed. According to the systemic interpretation of the information on the content, systematic qualitative and quantitative composition, biofacial features, spatio-temporal distribution in terrigenous-carbonate and terrigenous-siliceous formational complexes the spatio-temporal cyclicity, correlation levels, horizons-rapper for benthic, secretional and agglutinated foraminifera connected with the geodynamic and paleogeographic differentiation were proved. The correlation with zonal units of carbonate plankton is showed and their synchronicity with siliceous and carbonate benthos is proved. The units established by foraminifers of different regions of Ukraine correspond to Crimean-Caucasian zonal scale and correlated with biochronological zones of the International Stratigraphic Shart.

Key words: Paleogene of Ukraine, plankton and benthic foraminifera, methods and principles of detailed stratification, correlation.

\section{АЕТААЬНА СТРАТИФІКАЦІЯ ТА КОРЕАЯЦІЯ ПААЕОГЕНОВИХ ВІАКАААІВ УКРАЇНИ ЗА ФОРАМІНІФЕРАМИ}

\author{
Н.В. Маслун ${ }^{1}$, Л.Г. Мінтузова², С.Р. Гнилко ${ }^{3}$ \\ (Рекомендовано акад. НАН Украӥни П.Ф. Гожиком)
}

${ }^{1}$ Інститут геологічних наук НАН України, Київ, Україна, E-mail: ivanik_m@ukr.net

Кандидат геолого-мінералогічних наук, провідний науковий співробітник.

2 Львівське відділення УкрНДГРІ, Львів, Україна.

Кандидат геологічних наук, старший науковий співробітник.

${ }^{3}$ Інститут геології і геохімії горючих копалин НАН України, Львів, Україна, E-mail: s.hnylko@mail.ru Молодший науковий співробітник.

Наведено зональний розподіл дрібних форамініфер з палеогенових відкладів Тетичної і «бореальної» Північно-Атлантичної провінцій України. За системною інтерпретацією інформації 3 вмісту, систематичного якісного та кількісного складу, біофаціальних особливостей, просторово-часового розподілу в теригенно-карбонатних і теригенно-кременистих формаційних комплексах обгрунтовано просторово-часову циклічність, кореляційні рівні, горизонти-репери за бентосними, секреційними й аглютинованими форамініферами, що пов'язані з геодинамічною і палеогеографічною диференціацією. Наведено кореляцію з зональними підрозділами по карбонатному планктону і доведено їх синхронність з кременистим та карбонатним бентосом. Підрозділи, встановлені за форамініферами різних регіонів України, відповідають КримськоКавказькій зональній шкалі і корелюються з біохронологічними зонами Міжнародної стратиграфічної шкали (International Stratigraphic Shart).

Ключові слова: палеоген України, планктонні та бентосні форамініфери, методи і принципи детальної стратифікації, кореляція.

(c) N.V. Maslun, L.G. Mintuzova, S.R. Hnylko, 2015 


\title{
ДЕТАЛЬНАЯ СТРАТИФИКАЦИЯ И КОРРЕЛЯЦИЯ ПАЛЕОГЕНОВЫХ ОТЛОЖЕНИЙ УКРАИНЫ ПО ФОРАМИНИФЕРАМ
}

\author{
Н.В. Маслун1, Л.Г. Минтузова², С.Р. Гнилко ${ }^{3}$
}

(Рекомендовано акад. НАН Украины П.Ф. Гожиком)

\begin{abstract}
${ }^{1}$ Институт геологических наук НАН Украиньл, Киев, Украина, E-mail: ivanik_m@ukr.net Кандидат геолого-минералогических наук, ведущий научный сотрудник.

2 Львовское отделение УкрНИГРИ, Львов, Украина. Кандидат геологических наук,старший научный сотрудник.

${ }^{3}$ Институт геологии и геохимии горючих ископаемых НАН Украины, Львов, Украина, E-mail: s.hnylko@mail.ru Младший научный сотрудник.
\end{abstract}

Приведено зональное распределение мелких фораминифер из палеогеновых отложений Тетической и «бореальной» Северо-Атлантической провинций Украины. По системной интерпретации информации по содержанию, систематическому качественному и количественному составу, биофациальным особенностям, пространственно-временному распределению в терригенно-карбонатных и терригенно-кремнистых формационных комплексах обоснованы пространственно-временная цикличность, корреляционные уровни, горизонты-реперы по бентосным, секреционным и агглютинированным фораминиферам, связанные с геодинамической и палеогеографической дифференциацией. Приведена корреляция с зональными подразделениями по карбонатному планктону и доказана их синхронность с кремнистым и карбонатным бентосом. Подразделения, установленные по фораминиферам разных регионов Украины, соответствуют Крымско-Кавказской зональной шкале и коррелируются с биохронологическими зонами Международной стратиграфической шкалы (International Stratigraphic Shart).

Ключевые слова: палеоген Украины, планктонные и бентосные фораминиферы, методы и принципы детальной стратификации, корреляция.

\section{Introduction}

Paleogene deposits in Ukraine are located within the East European platform and its frames $-a$ number of back-arc seas of Alpine folded belt. These sedimentary basins that existed in the disclosure of Mezotethys and Paratethys paleooceans, are characterized by changing spatial-temporal style of tectonic movements, paleooceanographic environments with a variety of igneous and sedimentation processes.

Sedimentary cover of the western and southern Ukraine - the Carpathians, the Black Sea, the Azov Sea, Crimea, Kerch peninsula, Azov and Black Sea basin is represented by fragments of back-arc paleorifts of Cretaceous-Cenozoic age superimposed mainly on Eastern European paleokraton and foredeeps (Carpathian, Dobrudja, Indole-Kuban, Black Sea, Karkinitsko-Pivnichnokrymsky), which formed in Late Jurassic, Early Cretaceous, OligoceneQuaternary times.

In structural terms, there are the fragments of sedimentary basins reflected in the stratigraphic structure of Phanerozoic lithodynamical formational complexes which formed in different sedimentary and geodynamic conditions.
In the Carpathian-Black Sea region of Tethys the most complete sections of Paleocene deposits are specified, which in terrigenous-carbonate, terrigenous-siliceous and carbonate formations contain a variety of microfossils - foraminifera, nanoplankton, dinoflagellates, diatoms, radiolarians, spicules of sponges that enables detailed stratification, zoning, different correlation of deposits, development of detailed local regional scales and their correlation with ISS.

When zoning and development of detailed local Paleogene stratigraphy of western and southern regions of Ukraine, except main factors - litho- and biostratigrafic, there should be the engagement of information of structural and tectonic structure of the regions, lithodynamics of formational complexes from the position of back-arc-riftogeneous deflection of the Crimean and Black Sea rifts of CretaceousCenozoic age.

Within the northern Ukraine (the territory of the East European platform) the epicontinental basins of Paleoathlantic «boreal» ocean developed. In the stratigraphic structure of this region, which differs from the southern one by incomplete sections, due to the mainly noncarbonate 
sedimentation the paleogeographic connections between Tethys and Paleo-Atlantic (boreal) basins are clearly traced. The stage standards of Paleogene ISS are set in the Anglo-ParisianBelgian Basin of Paleo-Atlantic province where geological units usually are incomplete, causing much discussion in the inter-regional and regional correlations as well as the development of detailed stratigraphy of Paleogene in the northern Ukraine, especially when for the local units the high rank nomenclature is used divisions, subdivisions. To clarify the spatiotemporal structure of local and regional stratigraphic units, the substantiation of different rank stratigraphic units, their correlation with ISS, it is necessary to use biostratigraphic, lithological, facial, geophysical, sedimenthological, paleogeographic methods.

Paleogene sediments of Ukraine form a nearly continuous cover both in platform and geosynclinal zones in different paleoclimatic zones, have a complex stratigraphic structure with different lithofacies and characteristic for them complexes of organic residues of macro- , microplaktonic and benthic fauna and flora. According to these groups the age of different rank stratigraphic units is justified and prominent role among them belongs to foraminifera group which is orthostratigraphic in the Paleogene stratigraphy, accotding to which the detailed stratification and justification of volume and age, correlation of local, regional stratigraphic units was made.

The first attempt of detailed dissection and correlation of Paleocene deposits of Ukraine is showed in works of P.A. Tutkovsky (1903-1930), who started the microfaunal analysis by foraminifers and performed correlation. Foraminifera were also studied by Y.H. Gzhybovsky, K.K. Fott and V. Ulig. Almost all stratigraphic works with detailed stratification of Paleogene sediments were accompanied by microfaunal research and due to the work of a large group of paleontologists who studied foraminifera in research and production institutions. There are V. M. Benyamovsky (1980-2014), N.Ya. Boyaryntseva (1968, 1971, 1974), N.Ye. Brazhnikova (1936), E.M. Bugrova (1988, 2006), V.P. Vasylenko (1950-1963), I.V. Venglinsky (1968-1977), G.M. Voloshyna (1961-1990), O.S. Vyalov (1968), L.M. Holubnichaya (1958-1980), A.D. Gruzman (19631994), N.V. Dabagyan (1958-1994), L.G. Dayn (1939), V.E. Zhelezhyak (1968, 1969), M.M. Ivanik (1967-2008), V.K. Kaptarenko-Chornousova (1936-1971), T.A. Kyrylova (1971), I.D. Konen- kova (1967-1977), E.Ya. Krayeva (1954-1993), O.S. Lypnyk (1953-1972), N.I. Maslakova (1955. 1957), N.V. Maslun (1966-2014), M.O. Menkes (Tkachuk) (1967-1980), V.G. Morozova (1960, 1967), O.V. Myatlyuk (1955-1970), Yu.P. Nikitina (1963), A.P. Pechonkina (1953-1980), L.S. Pyshvanova (1960-1984), L.V. Prosnyakova (Ivanova) (1956-1983), T.S. Ryabokon (2005-2014), N.G. Savenko (1963-1977), R.B. Samoylova (19401947), G.D. Sobolev (1950-1967), N.N. Subbotina (1953, 1960), T.A. Ulanovska (1980-2014), P.A. Tutkovsky (1887-1925), A.V. Fursenko, O.N. Shvemberger (1967), K.K. Shutska (19581980), M.V. Yartseva (1951-1990) [1-108].

These studies contain information on stratigraphy of Paleogene by foraminifera, spatial and temporal distribution of planktonic and benthic foraminifera complexes, specific features of different rank biostratigraphic scales. In the Paleogene stratigraphy of Crimean-Caucasian segment of Tethys basin the Crimea sections are considered as stratotype ones, paleontological knowledge of which is quite high, including foraminifera, and plankton, which is orthostratigraphic group at different rank correlations including global. This applies to the Carpathian Paleogene sections. International zoning standards for the Paleogene planktonic foraminifera are in ISS by Berggren et al. (1995, 1998, 2000). But the idea of a zonal scale for the sub-tropical regions belongs to N.N. Subbotina (1936-1960). Her following studies (1939-1960), Morozova (1939-1967), Shutska (1974), G. Boli, W. Blow made possible the creation of zonal scales on planktonic foraminifera that have been transformed by W. Berggren as an international stratigraphic standard and now are used in almost all schemes [Fig. 1]. In zonal stratigraphy of Paleogene of Crimea-Caucasus region V.A. Krasheninnikov biozonal schemes are the most widely used, and demonstrated in his fundamental work (2007) and in V.M. Benyamovsky (2001).

A detailed study of Paleogene foraminifera with different structural-tectonic, geodynamic, morphostructural, lithofacial, paleosedimenthological features in the sections of the territory of Ukraine, located within the East European platform and its framing number of back-arc seas of geosynclinal Tethian belt demonstrates not only the significant differences in the distribution of plankton, benthic groups of local and regional units but the large separating capacity of this group for detailed stratification with zoning, correlations at the regional and global levels. 


\section{Research methods and material}

Logistics of our research consists of study of all available materials on foraminifers of Paleocene deposits of Ukraine, including the detailed dissection of cuts, analysis of spatio-temporal confinedness of foraminifera complexes in different structural-tectonic, morphostructural, sedimenthological areas. The analysis of foraminifera complexes was carried out, their taxonomic composition and structure, spatiotemporal distribution of the zonal divisions, differences of paleoecological parameters in the Paleogene sections within the East European platform (boreal type), and the Alpine geosynclinal belt (subtropical type), dependence of plankton and benthic foraminifera on paleoenvironment were determined.

An important part of the methodical block is the study of volumes, age of different rank stratigraphic units, their correlation, determining of differences of stratigraphic scales for planktonic foraminifera, establishing of criteria of local and zonal scales association into a large stratigraphic units (regiostage, stage, subdivision, division), possibility of their application to determine diachronous and isochronous boundaries. In determining of stratigraphic structure, especially in terrigenous cyclical sequences, biostratigraphic, lithologic and seismo-stratigraphic methods were used. An integrated approach is particularly necessary to establish volumes, fullness and gaps in sections.

The results of individual author studies of numerous sections, outcrops and drills in Paleogene deposits of Carpathian, Southern (Black Sea, Flat Crimea, the Crimean foothills, Kerch Peninsula, Azov-Black Sea waters) and Northern (Ukrainian shield, Dnieper-Donets depression) regions of Ukraine, processing of large information on the spatial and temporal distribution of planktonic and benthic foraminifera in the Paleogene revealed the distribution of different groups of foraminifera - plankton, benthic (secretional and agglutinated), reference levels of foramirifera complexes distribution in Paleocene-Eocene-Oligocene sections, their cyclicity in formational complexes. The completeness of sections was analyzed and the gaps were found. The specifics of zonal distribution of different rank zonal scales is presented. Correlation levels are traced. To this, the complex interpretation of materials of Paleogene cuts was applied.

For a comprehensive analysis of foraminifera which were the main factor, the thick- ness, fullness of section, gaps, inconsistencies, transition layers in the formational complexes were analyzed. An integrated approach to the interpretation of the distribution of foraminifera, which included the analysis of lithostratigraphic, morphostructural, tectonic data in $\mathrm{Pa}$ leocene deposits in different regions helps to avoid mistakes in detailed stratigraphic constructions.

According to the results of the materials interpretation by bio- and lithostratigraphic criteria based on morphostructural and tectonic data in Paleogene (Palaeocene, Eocene, Oligocene-Miocene (Maikop, menilite)) deposits of the studied regions, the local and regional gaps and inconsistencies were identified, stratigraphic range of which had different volumes. The most significant gaps are observed in areas of geomorphologically expressed paleo-elevations both local and regional. The gaps were singled out in sections on seismic profiles, but it is very difficult to set them in discrete points (individual outcrops of wells). Available in section outcrops sediments are only a small fraction of the formations of appropriate geological period. The vast majority of sedimentary complexes is not fixed in the section and there are hidden gaps - diastema.

The gaps in the areas of underwater erosion under the influence of currents, underwater landslides, gravity processes, olistostromes and clinoforms separation were traced. In clarifying of the nature of these processes, and in detailed stratification considerable attention was paid to the impact of litho-facies, tectonicgeodynamic, anoxic events on the distribution of foraminifera, especially on large different rank restructuring levels, justification of boundaries and transitional layers, redeposition of microfossils and foraminifera particularly in the Paleogene sediments of Carpathian-CrimeanBlack Sea segment of the Tethys. Such phenomena were found in Paleogene sections of Carpathians (Cretaceous - Paleocene boundary, Yamnenska suite), Eocene (Manyavska, Vygodska, Bystrytska suites), Oligocene (Menilite-Krosno) deposits, a phenomenon is quite common at various stratigraphic levels of Oligocene-Miocene Menilite and Krosno deposits, especially in the lower part, in PolyanytskoVorotyshche sediments where olistostromes are present (underwater-landslide). In Paleogene sediments of platform Ukraine, including Palaeocene (stratotype sections of Sumy regiostage of Luzanivsky and Kaniv strato- 
regions), Eocene (Kyiv, Obukhov regiostages). Considerably affected the stratigraphic structure, completeness of sections on the northwestern shelf and continental slope of West Black Sea depression, Kerch shelf and Eest Black Sea depression were different rank gaps and inconsistencies, which were found in thick abyssal fans of paleo-Danube, paleo-Dniester, paleo-Dnieper, and Indole-Kuban basin, Kerch peninsula - a large platform river paleo-DonKuban, and accumulation of debris sediments from rock paleo-Crimea. Similar phenomena are traced in sections of Carpathians, such as Paleocene deposits of old-Striy. Besides, the local character of gaps is due to erosion incisions, small water streams (contourites and stratiform bottom currents).

\section{Zoning by planktonic and benthic foraminifera}

As a result of the definition of a systematic composition and analysis of the distribution of foraminifera (Fig. 1,2) in the studied sections the significant similarities with complexes of foraminifera of even-aged deposits of the Crimea and the Caucasus were revealed. This gave grounds to establish in these sediments zones of detailed zonal scale of lower Paleogene of Crimean-Caucasian region (2001) and biochronological scale of W. Berggren (1995). According to the result of these studies the scheme of distribution of planktonic and benthic foraminifera in the Paleogene deposits of Ukraine was created, which shows the value and role of plankton, benthic secretional and agglutinated foraminifera in local and regional stratons, demonstrates a correlation of all groups of foraminifera within the Ukrainian Carpathians, the northern and southern regions of Ukraine with different rank stratons of surrounding areas and ISC.

In Paleogene the following zones are distinguished by the planktonic foraminifera and synchronous to them layers, horizons, markers.

Parvularugoglobigerina eugubina zone (H. Luterbacher, Silva I. Premoli, 1964) - the lowest part of the Danian stage. It is determined by the appearance of zonal taxon Parvularugoglobigerina eugubina at the bottom of Bilokamyansky regiostage in Black Sea basin, Crimean Peninsula, Azov-Black Sea waters and in Metovska suite of the South slope of the Carpathians. It corresponds to zone $\mathrm{P}$ of the International total scale (2004). It is similar to zones of the same name in South-Eastern
Crimea, Eastern Mediterranean, Western Turkmenistan, Caribbean, tropical and subtropical regions of the Pacific Ocean.

Eoglobigerina taurica zone (Morozova, $1960=$ Globigerina taurica) - the lower part of the Danian stage. It is defined by the presence of zonal taxon Eoglobigerina taurica at the bottom of Bilokamyansky regiostage in Crimea, Black Sea shelf and Nothen Black Sea coast. It corresponds to the zone PP1 of the CrimeanCaucasian region.

Globoconusa daubjergensis - Parasubbotina pseudobulloides zone (V.P. Alimarina, 1961) - the middle part of the Danian stage. It is determined by the presence of zonal taxa Globoconusa daubjergensis and Parasubbotina pseudobulloides at the bottom of Bilokamyansky regiostage in Kerch Peninsula and Black Sea shelf. This zone corresponds to Globoconusa daubjergensis zone of Crimea, Nothen Black Sea coast and also Psolskyi horizon of Nothen regions of Ukraine. It is correlated with zone PP2 of Crimean-Caucasian region and subzones P1b and P1c of the International total scale (2004). It is compared with Parasubbotina pseudobulloides zones in the Caucasus and the Caribbean region; Parasubbotina pseudobulloides-Subbotina triloculinoides in Armenia; Globoconusa daubjergensis in Tarkhankut area of the plain Crimea, Azerbaijan, Western Turkmenistan, Eastern Mediterranean.

Praemurica inconstans zone (Subbotina, 1953; = Globigerina inconstans) - the upper part of the Danian. It is defined by the presence of Praemurica inconstans zonal taxon and Parasubbotina trivialis, Acarinina schachdagica, Globigerina pseudotriloba species in the middle part of the Bilokamyansky horizon in Crimea, Kerch Peninsula, Black Sea shelf and Nothen Black Sea coast. Characteristic taxa of this zone was found in the middle part of Sumsky horizon. This zone corresponds to the zone PP3 of the Crimean-Caucasian region, similar to zones of Caucasus, Turkmenistan, Kazakhstan, Armenia, Caribbean Region, Eastern Mediterranean, the Atlantic boreal region.

In the Carpathians Globoconusa daubjergensis - Parasubbotina pseudobulloides and Praemurica inconstans zones correspond to Globoconusa daubjergensis zone, located at the top of Rusychansky regiostage (upper subsuite of Stryiska suite).

Morozovella angulata zone (Khalilov, 1948; = Globorotalia angulata) - the lower part of the Selandian. It is defined by the appearance 


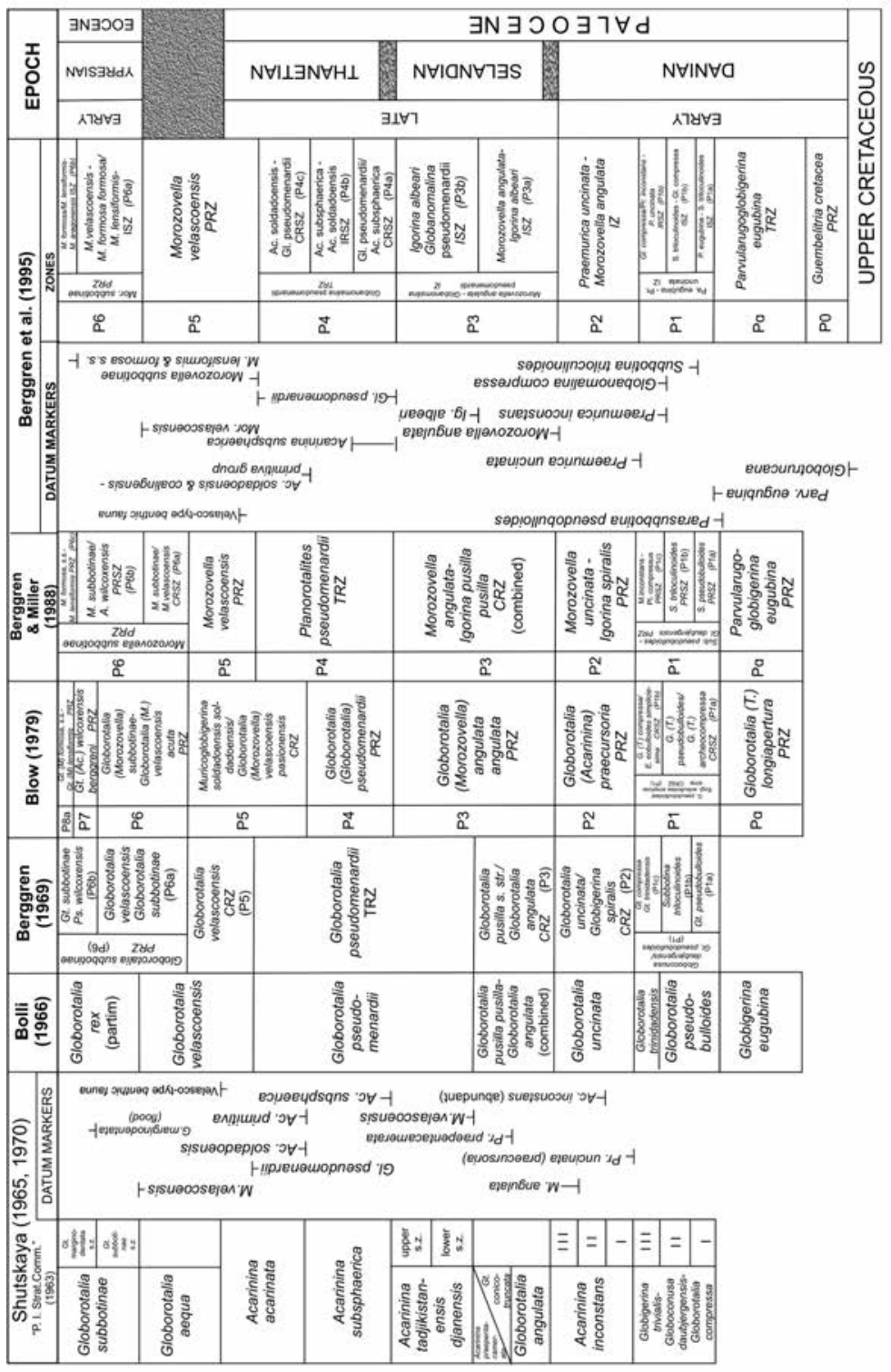

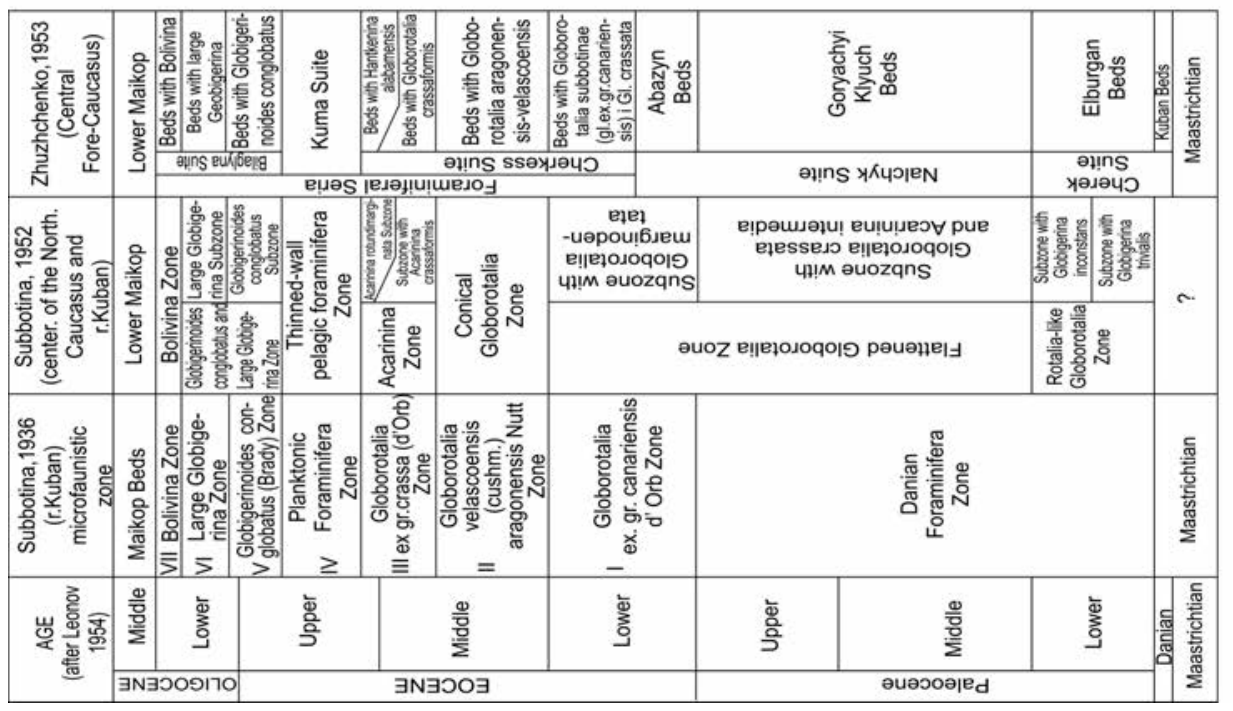



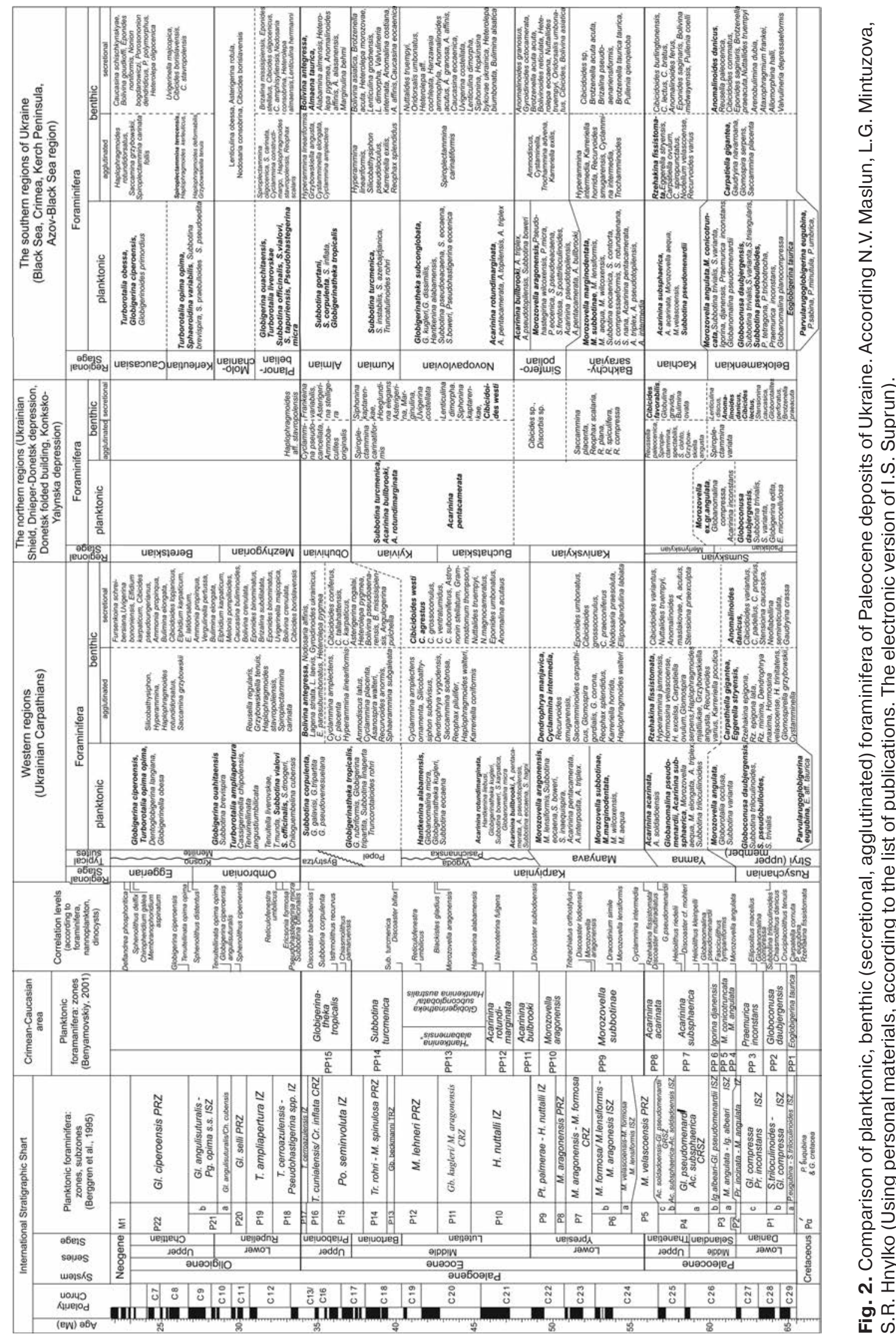
of zonal taxon Morozovella angulata at the top of the section of Bilokamyansky horizon in Crimea, Kerch Peninsula, Black Sea shelf and Nothen Black Sea coast and also in Metovska suite of the Carpathians. Characteristic taxa of this zone was found in the middle part of Sumsky horizon. This zone is compared with PP4 zone of the detailed zonal scale of CrimeanCaucasian region and subzone P3a of the total zonal scale of planktonic foraminifera that determines its stratigraphic position and allows us to date the rocks as Selandian. It is correlated with the same zone of the Caucasus, Georgia, Armenia, Azerbaijan, Kazakhstan, Turkmenistan and Caribbean region.

Morozovella conicotruncata zone (Subbotina, 1953; = Globorotalia conicotruncata) the upper part of the Selandian. It is determined by the appearance of zonal taxon Morozovella conicotruncata and taxon Globanomalina pseudomenardii in the top of Bilokamyansky horizon in Crimea, Kerch Peninsula and Nothen Black Sea coast. It corresponds to the zone PP5 of Crimean-Caucasian scale. Similar zones are Caucasus, Kazakhstan, Georgia, Turkmenistan.

Acarinina subsphaerica zone (Shutska, 1956) - the lower part of the Thanetianian. It is defined by the presence of numerous samples of zonal taxon Acarinina subsphaerica and appearance of Globanomalina elongata at the bottom of Kachynsky horizon in Crimea, Kerch Peninsula, Black Sea shelf and nothern Black Sea Coast. It corresponds to the zone PP7 of Crimean-Caucasian scale. Similar zones are Western Crimea, the Caucasus, the western part of Central Asia, Azerbaijan, Turkmenistan.

In the Carpathians Morozovella conicotruncata and Acarinina subsphaerica zones correspond to Globanomalina pseudomenardii zone found in carbonate sediments of the South slope (Metovska and Bilovezka suites).

Acarinina acarinata zone (Shutska, 1956) the upper part of the Thanetianian. It is defined by the presence of numerous specimens of zonal taxon Acarinina acarinata and taxa Subbotina velascoensis, Acarinina soldadoensis and Morozovella velascoensis in the top of Kachynsky horizon in Crimea, Kerch Peninsula and Nothern Black Sea coast and on the southern slopes of the Carpathians (Bilovezka and Sushmanetska suites). It corresponds to the zone PP8 of Crimean-Caucasian scale. It is similar to the zones of Crimean region, the Caucasus, west of the Central Asia, Georgia, Azerbaijan and Kazakhstan.
Agglutinated foraminifera zone (Khalilov, 1948) - the Thanetianian. It is defined in the deposits of Kachynsky horizon in all drilling areas by the presence of numerous agglutinated benthic foraminifera complex (in the absence of plankton and secretional benthos) Hyperammina cylindrica, Glomospira charoides, Ammodiscus subangustus, A. incertus, Bathysiphon dubia, Saccammina complanat, Subtilina tenius Nodellum velascoens, e Trochammina advena, Trochamminoides ammonoides, Recurvoides pseudoregularis, $R$ varius, Cystamminella grzybowskii, Rzehakina fissistomata, C. pseudopauciloculata, Karreriella horrida, K. danica, Spiroplectammina spectabils $S$. agglutinans. For species composition it is compared with the foraminifera complex of Garyachy Klyuch suite of the North Caucasus. The deposits of Thanetian (Acarinina acarinata and $A$. subsphaerica zones) in the Caucasus sections are characterized by the similar complex. It is compared with Rzehakina fissistomata zone of Carpathians, even-aged foraminifera complex of Garyachy Klyuch of North Caucasus, Karreriella zolkaensis zone of Eastern Crimea (Nasypkoyska ravine section), similar to the zone of Western Turkmenistan. Its deposits are distributed on the Kerch Peninsula and may be the stratigraphic marker of the Upper Paleocene.

In the Carpathians numerous agglutinated foraminifera (without calcareous fossils) are common in low depth horizon of red and green mudstone, which corresponds to the bottom of Manyavska suite. The lower part of this horizon refers to Paleocene by the findings of Rzehakina fissistomata species, and the top - to the lower Eocene by the findings of Saccamminoides carpathicus species and lack of the characteristic Palaeocene fauna. Multiple and diverse in species and composition "Glomospira» are characteristic of these deposits.

Morozovella subbotinae zone (Morozova, 1946; = Globorotalia subbotina) - the lower part of the Ypresian. It is defined by the presence of zonal taxon Morozovella subbotinae or taxon Morozovella marginodentata in deposits of Bakhchysaray horizon in Crimea, Kerch Peninsula, Black Sea shelf and Nothern Black Sea coast and in the Metovska suite of the Carpathians. It corresponds to the zone PP9 of the Crimean-Caucasian scale. Similar zones are Caucasus, Georgia, the Caribbean region, Armenia, Azerbaijan, Kazakhstan, Turkmenistan, the boreal region of the Atlantic Ocean. 
Morozovella aragonensis zone (Khalilov, 1948; = Globorotalia aragonensis) - the upper part of the Ypresian stage except the top strata. It is determined by the appearance of Morozovella aragonensis, M. caucasica, Subbotina eocaena, S. boweri, Pseudohastegirina micra in Crimea, Kerch Peninsula, Black Sea shelf and Nothern Black Sea coast and in the Metovska suite of the Carpathians. In terrigenous and siliceous facies in this range the segments on benthos foraminifera are identified (Fig 2). It corresponds to the zone PP10 of the Crimean-Caucasian scale. It is compared with similar zones of the Lower Eocene of Caucasus, Georgia, Armenia, Azerbaijan, Kazakhstan, the Caribbean region, Turkmenistan, the boreal region of the Atlantic Ocean.

Acarinina bullbrooki zone (Subbotina, 1939; = Globorotalia crassaformis) - the top strata of the Ypresian and the lower strata of the Lutetian. It is determined by the appearance of numerous samples of zonal taxon Acarinina bullbrooki together with species Acarinina pentacamerata and Acarinina pseudotopilensis in deposits of the top part of Simferopol regiostage in Crimea, Kerch Peninsula, Black Sea shelf and Nothern Black Sea coast and in the Metovska and Bilovezka suites of the Carpathians. It corresponds to the zone PP11 of the Crimean-Caucasian scale. It is compared with similar zones of the Crimea, the Caucasus, Georgia, Armenia, Kazakhstan and Turkmenistan.

Acarinina rotundimarginata zone (Subbotina, 1953) - the lower part of the Lutetian except its lowest strata. The zone is defined by the appearance of zonal taxon Acarinina rotundimarginata and presence of taxa Subbotina eocaena, S. boweri and Pseudohastegirina micra in sediments of the bottom of Novopavlivsky horizon in Crimea, Kerch Peninsula and Nothern Black Sea coast. It is seperated by the large occurrence of zonal taxon Acarinina rotundimarginata and species Hantkenina liebusi and Globigerinatheka kugleri in the Metovska and Bilovezka suites of the Carpathians. It corresponds to the zone PP12 of the Crimean-Caucasian scale. It is compared with similar zones of the Crimea, the Caucasus, Georgia, Armenia, Azerbaijan, Eastern Mediterranean, Kazakhstan.

Globigerinatheka subconglobata zone (Shutska, 1970; = Globigerinoides subconglobata) - the top part of the Lutetian. It is determined by the appearance of numerous specimens of zonal taxon Globigerinatheka subconglobata in the top of the Novopavlivsky horizon in Crimea, Kerch Peninsula, Black Sea shelf and Nothern Black Sea coast. It corresponds to subzones $G$. subconglobata and G. index of PP13 zone of the Crimean-Caucasian scale. It is compared with similar zones of the Caucasus, Azerbaijan, Turkmenistan.

Subbotina turcmenica zone (Khalilov, 1948; = Globigerina turcmenica) - Bartonian. It is determinated by the appearance of zonal taxon Subbotina turcmenica in Kumskyi horizon in Crimea and Nothern Black Sea coast. It corresponds to the zone PP14 of the CrimeanCaucasian scale. In the Carpathians Subbotina turcmenica zone corresponds to Hantkenina alabamensis zone found in Metovska suite.

Globigerinateka tropicalis zone (Subbotina, 1939; = Globigerinoides conglobatus) the Priabonian. It is defined in the deposits of Alminsky horizon in Crimea, Kerch Peninsula, Black Sea shelf and Nothern Black Sea coast by the occurrence of zonal taxon Globigerinateka tropicalis and taxon Subbotina corpulenta. It corresponds to the zone PP15 of the Crimean-Caucasian scale. It is compared with similar zones of the Caucasus, Kazakhstan and Turkmenistan.

In the Carpathians the Globigerinateka tropicalis s. str. and Subbotina corpulenta zones are outlined. The zone Subbotina corpulenta corresponds to nanoplankton zone NP21 and allocated in regionally distributed horizon of "globigerine marl" located in the border layers of Karpiysky and Ombronsky regiostages.

Stratigraphic distribution of foraminifera in Oligocene sediments of Ukraine derives from the variety of structural and tectonic and sedimentological conditions in the southern oil-bearing province (Black Sea, Crimea, Azov-Black Sea water area), and in Western Ukraine.

Analysis of the vertical and lateral distribution of foraminifera (planktonic and benthic) allowed allocating different rank biostratigraphic units in the rank of provincial areas. In menilite, Krosnenska suites of Carpathians, in Planorbelovy, Molochansky, Kerleutsky, Caucasian regiostages of Tethys segment of South Ukraine (Fig. 2).

The small planktonic foraminifera characterize the Ombronsky and the lower part of Egersky regiostage (Oligocene) of the Carpathians. There were identified: layers of Subbotina affcinalis, Globigerina vialovi; zone Turborotalia liverovskae; zone Cassigerinella 
chipolensis; zone Globigerina ampliapertura; layers of Turborotalia opima opima-Globigerina ciperoensis.

Biostratification of Paleogene sediments by benthic foraminifera - secretional and agglutinated - is widely held as in the Carpathian and in the southern regions of Ukraine. It is noted similarities in species composition of characteristic benthic foraminifera in even-aged sediments of different regions. Thus, for the Palaeocene associations agglutinated Carpatiella gigantea (in the lower parts), Carpatiella ovulum, Rzehakina fissistomata, Eggerella stryensis and secretional Anomalina danica, Stensioina caucasica, Reusella paleocenica are typical. In the Eocene noncalcareous sediments agglutinated foraminifera, especially the genera $\mathrm{Hy}$ perammina, Haplophragmoides, Recurvoides, Cyclammina are important for stratification and correlation, but in the calcareous - secretional, especially the genera Anomalina, Heterolepa, Bolivina, Cibicidoides. Different species and subspecies of which occur at different levels throughout the Paleogene section. The Early Eocene associations characterize the species Hyperammina intermedia, Cyclammina intermedia, the Middle Eocene - Hyperammina

\section{References}

1. Андреєва-Григорович А.С., Іванік М.М., Маслун Н.В. та ін. Регіояруси палеогену Українських Карпат. В кн.: Проблеми стратиграфії фанерозою України: Зб. наук. пр. ІГН НАН України. Київ, 2004. C. 105-109.

Andreyeva-Grigorovich A.S., Ivanik M.M., Maslun N.V. et al., 2004. Paleogene regiostages of Ukrainian Carpathians. In: Problems of stratigraphy of Phanerozoic Ukraine: Coll. Sci. works of IGS of NAS of Ukraine. Kyiv, p. 105-109 (in Ukrainian).

2. Андреева-Григорович А.С., Грузман А.Д. О комплексах фораминифер и нанопланктона в стратотипе менилитовой свиты по р. Чечве. Палеонтол. сб. 1978. № 15. С. 83-89.

Andreyeva-Grigorovich A.S., Gruzman A.D., 1978. On the complexes of foraminifera and nanoplankton in stratotype of Menilite series on the river Chechva. Paleontologicheskiy sbornik, № 15, p. 83-89 (in Russian).

3. Андреєва-Григорович А.С., Грузман А.Д., Коненкова І.Д. Кореляція олігоценових відкладів Українських Карпат та Північного Причорномор'я за планктонними мікроорганізмами. Палеонтол. зб. 1993. № 29. С. 73-78.

Andreyeva-Grigorovich A.S., Gruzman A.D., Konenkova I.D., 1993. Correlation of Oligocene sediments of Ukrainian Carpathians and the northern lineariformis, Cyclammina amplectens, Anomalina acuta, Anomalinoides acutus, the Late Eocene - Cyclammina placenta. Bolivina antegressa, Heterolepa pygmea. Oligocene sediments are correlated by the distribution of the genera Cibicides, Henticulina, Bolivina, Eponides, Uvigerinella, Spiroplectammina, Cyclammina, Haplophragmoides (Fig. 2).

\section{Conclusion}

Informative for detailed stratification and interregional correlations are all groups of foraminifera - planktonic, benthic agglutinated and secretional. Thus, the correlation of sediments on the planktonic foraminifera has interregional and global nature. The units of planktonic foraminifera set in different regions of Ukraine meet Crimean-Caucasian zonal scale and correlate with biochronological zones of International Stratigraphic Shart, 2009. The special composition of benthic - agglutinated and secretional foraminifera - may be significantly distinct in different facial stratons that helps clarify the differences in conditions of coeval deposits sedimentation and apply this group for interregional correlations.

Black Sea region by planktonic organisms. Paleontologichnyy zbirnyk, № 29, p. 73-78 (in Ukrainian).

4. Андреєва-Григорович А.С., Іванік М.М., Маслун Н.В. та ін. Регіояруси палеогену Українських Карпат. В кн.: Проблеми стратиграфії фанерозою України: Зб. наук. пр. ІГН НАН України. Київ, 2004. C. 105-109.

Andreyeva-Grigorovich A.S., Ivanik M.M., MasIun N.V. et al., 2004. Regiostages of Paleogene of Ukrainian Carpathians. In: Problems of Phanerozoic stratigraphy of Ukraine: Coll. Sci. works of IGS of NAS of Ukraine. Kyiv, p. 105-109 (in Ukrainian).

5. Андреєва-Григорович А.С., Іванік М.М., Маслун Н.В. та ін. Майкопський палеобасейн та його вікові аналоги (стратиграфія, еволюція біоти, осадконакопичення). Стратиграфия осадочных образований верхнего протерозоя и фанерозоя: Материалы Междунар. науч. конф. [Киев, 23-26 сент. 2013 г.]. Киев, 2013. С. 13-15.

Andreyeva-Grigorovich A.S., Ivanik M.M., Maslun N.V. et al., 2013. Paleobasin Maikop and its age analogs (stratigraphy, evolution of biota, sedimentation). The stratigraphy of sedimentary rocks of the Upper Proterozoic and Phanerozoic: Proceedings of the Intern. Sci. conf. [Kyiv, September 23-26, 2013]. Kyiv, p. 13-15 (in Ukrainian). 
6. Ахметьев М.А., Беньямовский В.Н. Стратиграфическая схема морского палеогена юга Европейской России. Бюл. Моск. о-ва испытателей природы. Отд. геол. 2003. Т. 78, вып. 5. С. 40-51.

Akhmetyev M.A., Benyamovsky V.N., 2003. Stratigraphic scheme of the Paleogene sea of the south of European Russia. Buleten Moscowskogo obshchestva ispytateley prirody. Otd. geol., vol. 78, iss. 5 , p. 40-51 (in Russian).

7. Дидковский В.Я., Зелинская В.А., Зосимович В.Ю. и др. Стратиграфические подразделения пограничных эоцен-олигоценовых отложений Северной Украины. Докл. АН УССР. Сер. Б. 1984. № 8. C. 9-12.

Didkovskiy V.Ya., Zelinskaya V.A., Zosimovich V.Yu. et al., 1984. Stratigraphic units of boundary Eocene-Oligocene sediments of North Ukraine. Doklady AN USSR. Ser. B, № 8, p. 9-12 (in Russian).

8. Беньямовский В.Н. Обоснование детальной стратиграфической схемы нижнего палеогена Крымско-Кавказской области. В кн.: Пути детализации стратиграфических схем и палеогеографические реконструкции. Москва: ГЕОС, 2001. C. 210-223.

Benyamovsky V.N., 2001. Justification of detailed stratigraphic scheme of the lower Paleogene of Crimean-Caucasus region. In: Ways of detalization of stratigraphic schemes and paleogeographic reconstructions. Moscow: GEOS, p. 210-223 (in Russian).

9. Беньямовский В.Н. Днепровско-Донецкий бассейн как связующее звено между морями северо-западной Евразии (по материалам палеоценовых бентосных фораминифер). В кн.: Викопна фауна і флора України: палеоекологічний та стратиграфічний аспекти: Зб. наук. пр. ІГН НАН України. Київ, 2009. С. 207-211.

Benyamovsky V.N., 2009. Dnieper-Donets Basin as a link between the seas of north-western Eurasia (based on benthic foraminifera of Paleocene) In: Fossil fauna and flora of Ukraine: stratigraphic and paleoecological aspects: Coll. Sci. works of IGS of NAS of Ukraine. Kyiv, p. 207-211 (in Russian).

10. Богданович А.К. Новые данные о стратиграфическом и пространственном распределении майкопской микрофауны Северного Кавказа. В кн.: Палеогеновые отложения юга европейской части СССР. Москва: Изд-во АН СССР, 1960. C. 245-276.

Bogdanovich A.K., 1960. New data on stratigraphic and spatial distribution of the Maikop microfauna of Northern Caucasus In: Paleogene deposits of the south European part of the USSR. Moscow: Izdatelstvo AN SSSR, p. 245-276 (in Russian).

11. Бугрова Э.М. Зональное деление эоцена Бахчисарайского района Крыма по мелким фораминиферам. Изв. АН СССР. Сер. геол. 1988. № 1. C. 82-90.
Bugrova E.M., 1988. Zonal division of the Eocene Bakhchisaray district of Crimea on small foraminifera. Izvestiya AN SSSR. Ser. geol., № 1, p. 82-90 (in Russian).

12. Бугрова Э.М. Стратиграфическое и географическое распространение верхнеэоценовых фораминифер на северной окраине бассейна Тетис. Стратиграфия. Геол. корреляция. 2001. T. 9, № 2. C. 92-104.

Bugrova E.M., 2001. The stratigraphic and geographic distribution of Upper Eocene foraminifera on the northern edge of the Tethys basin. Stratigrafiya. Geologicheskaya correlatsiya, vol. 9, № 2, p. 92-104 (in Russian).

13. Веселов А.А., Краева Е.Я., Савенко Н.Г. и др. Стратиграфия верхнеэоценовых отложений Причерноморской впадины. Геол. сб. Львов. геол. о-ва. 1971. № 13. С. 45-52.

Veselov A.A., Krayeva E. Ya., Savenko N.G. et al., 1971. Stratigraphy of the Upper Eocene sediments of the Black Sea basin. Geologicheskiy sbornik Lvovskogo geologicheskogo obshchestva, № 13, p. 45-52 (in Russian).

14. Вялов О.С. Палеогеновый флиш северного склона Карпат. Киев: Изд-во АН УССР, 1961. $135 \mathrm{c}$.

Vyalov O.S., 1961. Paleogene flysch of the northern slope of the Carpathians. Kiev: Izdatelstvo AN USSR, 135 p. (in Russian).

15. Вялов О.С., Гавура С.П., Даныш В.В. и др. Стратотипы меловых и палеогеновых отложений Украинских Карпат. Киев: Наук. думка, 1988. 204 c.

Vyalov O.S., Gavura S.P., Danysh V.V. et al., 1988. Stratotypes of Cretaceous and Paleogene deposits of the Ukrainian Carpathians. Kiev: Naukova Dumka, 204 p. (in Russian).

16. Вялов О.С. O Silicinifera - кремнистых фораминиферах. Палеонтол. сб. 1988. № 25. С. 12-19.

Vyalov O.S., 1988. About Silicinifera - siliceous foraminifers. Paleontologicheskiy sbornik, № 25, p. 12-19.

17. Гнилко О.М., Гнилко С.Р. Стратиграфія та умови седиментації еоценового флішу Кросненського (Сілезького) покриву Українських Карпат. Геол. журн. 2011. № 2 (335). С. 12-24.

Hnylko O.M., Hnylko S.R., 2011. Stratigraphy and conditions of sedimentation of Eocene flysch of Krosno (Silezky) cover of Ukrainian Carpathians. Geologichnyy zhurnal, № 2 (335), p. 12-24 (in Ukrainian).

18. Гнилко C.P. Стратиграфія і умови накопичення палеоценово-еоценових відкладів Вежанського і Монастирецького покривів Українських Карпат на основі вивчення дрібних форамініфер. В кн.: Еволюція органічного світу та етапи геологічного розвитку Землі: Матеріали XXXV cec. Палеонт. т-ва НАН України. Київ, 2014. С.81-83. 
Hnylko S.R., 2014. Stratigraphy and storage conditions of Palaeocene-Eocene sediments of Vezhansky and Monastyretsky covers of Ukrainian Carpathians based on the study of small foraminifera. In: Organic evolution and stages of geological development of the Earth: Proceedings of the XXXV ses. Paleont. soc. of NAS of Ukraine. Kyiv, p. 81-83 (in Ukrainian).

19. Гожик П.Ф., Маслун Н.В., Войницький З.Я. та ін. Стратиграфічна будова кайнозойських відкладів прикерченського шельфу та Східно-Причорноморської западини. Геол. журн. 2010. № 1 (330). C. 7-41.

Gozhyk P.F., Maslun N.V., Voynytsky Z. Ya. et al., 2010. Stratigraphic structure of Cenozoic sediments of Kerch shelf and East Black Sea basin. Geologichnyy zhurnal, № 1 (330), p. 7-41 (in Ukrainian).

20. Гожик П.Ф., Маслун Н.В., Плотнікова Л.Ф. та ін. Стратиграфія мезо-кайнозойських відкладів північно-західного шельфу Чорного моря. Київ, 2006. $171 \mathrm{c}$

Gozhyk P.F., Maslun N.V., Plotnikova L.F. et al., 2006. Stratigraphy of Mesozoic-Cenozoic sediments of the northwestern Black Sea shelf. Kyiv, 171 p. (in Ukrainian).

21. Гожик П.Ф., Митропольський О.Ю., Маслун Н.В., Цихоцька Н.Н. Особливості седиментогенезу в Чорноморській западині в кайнозої. В кн.: Геология и полезные ископаемые Черного моря. Киев, 1999. С. 210-214.

Gozhyk P.F., Mitropolsky A.Yu., Maslun N.V., Tsykhotska N.N., 1999. Features of sedimentogenesis in the Black Sea basin in the Cenozoic. In: Geology and Mineral Resources of the Black Sea. Kiev, p. 210-214 (in Ukrainian)

22. Гожик П.Ф., Семененко В.Н., АндрееваГригорович А.С. и др. Корреляция олигоценовых и неогеновых региоярусов Центрального и Восточного Паратетиса в пределах Украины. Стратиграфия осадочных образований верхнего протерозоя и фанерозоя: Материалы Междунар. науч. конф. (Киев, 23-26 сент. 2013 г.). Киев, 2013. C. 48-49.

Gozhik P.F., Semenenko V.N., Andreyeva-Grigorovich A.S. et al., 2013. Correlation of Oligocene and Neogene regiostages of the Central and Eastern Paratethys in Ukraine. Stratigraphy of sedimentary rocks of the Upper Proterozoic and Phanerozoic: Proceedings of the Intern. Sci. conf. (Kiev, September 23-26, 2013). Kiev, p. 48-49 (in Russian).

23. Грузман А.Д. Фораминиферы и стратиграфия олигоцена и нижнего миоцена Украинских Карпат: автореф. дис. ... канд. геол.-минерал. наук. Киев, 1983. 24 с.

Gruzman A.D., 1983. Foraminifera and stratigraphy of Oligocene and Miocene of the Ukrainian Carpathians: avtoref. dis. ... cand. geol.-mineral. sci. Kiev, 24 p. (in Russian).
24. Дабагян Н.В., Круглов С.С., Смирнов С.Е. Литология и стратиграфия мелового и палеогенового чехла зоны Закарпатских утесов. Тр. УкрНИГРИ. 1965. Вып. 14. С. 78-86.

Dabaghyan N.V., Kruglov S.S., Smirnov S.E., 1965. Lithology and stratigraphy of the Cretaceous and Paleogene cover of Transcarpathian area cliffs. Trudy UkrNIGRI, vol. 14. p. 78-86 (in Russian).

25. Жабіна Н.М., Мінтузова Л.Г. Модель геологічної будови південно-східного Криму. Геологія і геохімія горючих копалин. 2000. № 1. С. 25-35.

Zhabina N.M., Mintuzova L.G., 2000. The model of the geological structure of south-eastern Crimea. Geologiya i geokhimiya goryuchykh kopalyn, № 1, p. 25-35.

26. Зелинская В.А., Краева Е.Я. К стратиграфии верхнеэоценовыхи олигоценовых отложений Украины. Геол. журн. 1969. Т. 29, вып. 5 (128). C. 63-74

Zelinskaya V.A., Krayeva N.L., 1969. Stratigraphy of Upper Eocene and Oligocene sediments of Ukraine. Geologicheskiy zhurnal, vol. 29, iss. 5 (128), p. 63-74 (in Russian).

27. Зернецкий Б.Ф., Люльева С.А. Зональная биостратиграфия эоцена европейской части СССР. Киев: Наук. думка, 1990. 96 с.

Zernetsky B.F., Lyulyeva S.A., 1990. Zonal biostratigraphy of Eocene of the European part of the USSR. Kiev: Naukova Dumka, 96 p. (in Russian).

28. Зернецкий Б.Ф., Люльева С.А. Зональная биостратиграфия палеоцена Восточно-Европейской платформы. Киев: Наук. думка, 1994. 75 с.

Zernetsky B.F., Lyulyeva S.A., 1994. Zonal biostratigraphy of Paleocene of the East European platform. Kiev: Naukova Dumka, 75 p. (in Russian).

29. Зосимович В.Ю., Маслун Н.В., Люльева С.А., Плаксина Г.Л. Стратиграфические аналоги пограничных эоцен-олигоценовых отложений Украины и Поволжья. Геол. журн. 1988. № 4 (241). С. 63-70.

Zosimovich V.Yu., Maslun N.V., Lyuyleva S.A., Plaksina G.L., 1988. Stratigraphic analogues of border Eocene-Oligocene sediments of Ukraine and the Volga region. Geologicheskiy zhurnal, № 4 (241), p. 63-70 (in Russian).

30. Иваник М.М.. Маслун Н.В. Кремнистые микроорганизмы и их использование для расчленения палеогеновых отложений Предкарпатья. Киев: Наук. думка, 1977. 120 с.

Ivanik M.M., Maslun N.V., 1977. Siliceous microorganisms and their use for differentiation of $\mathrm{Pa}$ leogene deposits of Precarpathians. Kiev: Naukova Dumka, 120 p. (in Russian).

31. Иваник М.М., Маслун Н.В. Палеогеографические условия образования палеоценовых отложений в нефтегазоносных областях Украины. Литология осадочного чехла УССР (палеогеографический аспект): Материалы IV Респ. литол. совещ. Киев: Наук. думка, 1991. С. 264-267. 
Ivanik M.M., Maslun N.V., 1991. Paleogeographic conditions of formation of Paleocene deposits in oil and gas regions of Ukraine. Lithology of the sedimentary cover of the Ukrainian SSR (paleogeographic aspect): Proceedings of the IV Rep. litol. meet. Kiev: Naukova Dumka, p. 264-267 (in Russian).

32. Іванік М.М., Маслун Н.В. Кореляція зональної шкали палеогену України, Середземномор'я, Світового океану за планктонними форамініферами з палеомагнітною та хроностратиграфічною шкалами. Доп. НАН України. 2000. № 3. C. $128-132$.

Ivanik N.M., Maslun N.V., 2000. Correlation of zonal scale of Paleogene of Ukraine, Mediterranean, Oceans by planktonic foraminifera with paleomagnetic and chronostratigraphic scales. Dopovidi NAN Ukrainy, № 3, p. 128-132 (in Ukrainian).

33. Іванік М.М., Маслун Н.В., Сельський В.К. Про стратиграфічний поділ палеогенових відкладів південно-східної частини Внутрішньої зони Передкарпатського прогину. Доп. АН УРСР. Сер. Б. 1970. № 10. C. 894-896.

Ivanik M.M., Maslun N.V., Selskiy V.K., 1970. About Paleogene stratigraphic separation of deposits of the south-eastern part of the Inner Carpathian foredeep. Dopovidi AN URSR. Ser. B, № 10, p. 894896 (in Ukrainian).

34. Каптаренко-Черноусова О.К. Киевский ярус и элементы его палеогеографии. Киев, 1951. 178 с. (Тр. Ин-та геол. наук АН УССР. Сер. Стратиграфия и палеонтология; Вып. 3).

Kaptarenko-Chernousova O.K., 1951. Kiev Stage and the elements of its paleogeography. Kyiv, 178 p. (Trudy IGN USSR. Ser. Stratigrafiya i Paleontologiya; Iss. 3) (in Russian).

35. Каптаренко-Черноусова О.К. Зональное расчленение отложений киевского яруса. Докл. АН УССР. 1958, № 7. С. 772-775.

Kaptarenko-Chernousova O.K., 1958. Zonal division of deposits of Kiev Stage. Doklady AN USSR, № 7, p. 772-775 (in Russian).

36. Коненкова И.Д. Биостратиграфия датских и палеоценовых отложений Северного Причерноморья по фораминиферам: автореф. дис. ... канд. геол.-минерал. наук. Киев, 1972. 23 с.

Konenkova I.D., 1972. Biostratigraphy of Danian and Paleocene deposits of the Northern Black Sea foraminifera: thesis ... cand. geol.-mineral. sci. Kiev, 23 p. (in Russian).

37. Краева Е.Я. Стратиграфические расчленения киевской свиты юго-восточной части Днепровско-Донецкой впадины. Геол. журн. 1974. Т. 34, вып. 4 (157). С. 51-57.

Krayeva E. Ya., 1974. Stratigraphic division of the Kiev suite of south-eastern part of the DnieperDonets Depression. Geologicheskiy zhurnal, vol. 34, iss. 4 (157), p. 51-57 (in Russian).
38. Краева Е.Я. Геологический возраст асканийской и горностаевской свит Северного Причерноморья. Тектоника и стратиграфия. 1975. № 9. C. 76-84.

Krayeva E. Ya., 1975. Geological age of Ascanian and Gornostaevska suites of the Northern Black Sea. Tectonica i stratigrafiya, № 9, p. 76-84 (in Russian).

39. Краева Е.Я., Маслун Н.В. Значение бентоносных фораминифер для расчленения и корреляции палеогеновых отложений Украины. Геол. журн. 1984. № 4 (217). С. 107-112.

Krayeva E.Y., Maslun N.V., 1984. The value of benthic foraminifera for the subdivision and correlation of Paleogene deposits of Ukraine. Geologicheskiy zhurnal, № 4 (217), p. 107-112 (in Russian).

40. Краева Е.Я., Люльева С.А. Фораминиферы и зоны известкового нанопланктона палеогеновых отложений шельфа северо-западной части Черного моря. Изв. АН СССР. Сер. геол. 1976. № 10. C. 133-139.

Krayeva E. Ya., Lyulyeva S.A., 1976. Foraminifera and calcareous nanoplankton area of Paleogene deposits offshore north-western part of the Black Sea. Izvestiya AN SSSR. Ser. geol., № 10, p. 133-139 (in Russian).

41. Краева Е.Я., Маслун Н.В. Граница эоцена олигоцена Украины и сопредельных территорий по фораминиферам. Палеонтол. сб. 1987. № 24. C. 84-94.

Krayeva E. Ya., Maslun N.V., 1987. The boundary of the Eocene - Oligocene of Ukraine and adjacent territories on foraminifera. Paleontologicheskiy sbornik, № 24, p. 84-94 (in Russian).

42. Краєва Є.Я. Форамініфери верхньоеоценових та олігоценових відкладів північного крила Причорноморської западини. Київ: Вид-во АН УРСР, $1961.95 \mathrm{c}$.

Krayeva E.Ya., 1961. Foraminifera of the Upper Eocene and Oligocene sediments of the northern part of the Black Sea basin. Kyiv: Vydavnytstvo AN URSR, 95 p. (in Ukrainian).

43. Краєва Є.Я., Ярцева М.В. Характеристика планктонних форамініфер олігоцену Північного Причорномор'я. Доп. АН УРСР. Сер. Б. 1973. № 8. C. 693-696.

Krayeva E.Ya., Yartseva M.V., 1973. Characteristics of planktonic foraminifera of Oligocene of Northern Black Sea. Dopovidi AN URSR. Ser. B, № 8, p. 693-696 (in Ukrainian).

44. Крашенинников В.А., Басов И.А. Стратиграфия палеогеновых отложений Мирового океана и корреляция с разрезами на континентах. Москва: Науч. мир, 2007. 316 с. (Тр. ГИН РАН; Вып. 583).

Krasheninnikov V.A., Basov I.A., 2007. Stratigraphy of Paleogene deposits of the oceans and the correlation with sections on the continents. Moscow: Nauchnyi Mir, 316 p. (Trudy GIN RAN; Iss. 583) (in Russian). 
45. Крашенинников В.А., Серова М.Я., Басов И.А. Стратиграфия и планктонные фораминиферы палеогена высоких широт Тихого океана. Москва: Наука, 1988. 120 с. (Тр. ГИН; Вып. 429).

Krasheninnikov V.A., Serov M.Ya., Basov I.A., 1988. Stratigraphy and planktonic foraminifera of $\mathrm{Pa}$ leogene of high latitudes of the Pacific Ocean. Moscow: Nauka, 120 p. (Trudy GIN; Iss. 429) (in Russian).

46. Лукін О.Ю. Феномен пограничних стратонів та його значення для вирішення ключових проблем теоретичної та прикладної геології. Геол. журн. 2003. № 2 (304). С. 7-26.

Lukin O.Yu., 2003. Straton border phenomenon and its importance for addressing of key problems of theoretical and applied geology. Geologichnyy zhurnal, № 2 (304), p. 7-26 (in Ukrainian).

47. Маслакова Н.И. Стратиграфия и фауна мелких фораминифер палеогеновых отложений Восточных Карпат. В кн.: Материалы по биостратиграфии западных областей Украинской ССР. Москва: Госгеолиздат, 1955. С. 5-132.

Maslakova N.I., 1955. Stratigraphy and fauna of the small foraminifera of Paleogene deposits of the Eastern Carpathians. In: Materials on the biostratigraphy of the western regions of the Ukrainian SSR. Moscow: Gosgeolizdat, p. 5-132 (in Russian).

48. Маслакова Н.И. Стратиграфия верхнего мела Северного Кавказа и Крыма. Крым. В кн.: Атлас верхнемеловой фауны Северного Кавказа и Крыма. Москва: Гостоптехиздат, 1959. С. 60-84.

Maslakova N.I., 1959. The stratigraphy of the Upper Cretaceous of the North Caucasus and the Crimea. Crimea. In: Atlas of the Upper Cretaceous fauna of the North Caucasus and the Crimea. Moscow: Gostoptekhizdat, p. 60-84 (in Russian).

49. Маслун Н.В. Біостратиграфічна характеристика нижньоеоценових відкладів Внутрішньої зони Передкарпатського прогину. Геол. журн. 1976. Т. 36, вип. 2 (167). С. 103-110.

Mas/un N.V., 1976. Biostratigraphic characteristics of the Lower Eocene deposits of the Carpathian foredeep inner zone. Geologichnyy zhurnal, vol. 36, iss. 2 (167), p. 103-110 (in Ukrainian).

50. Маслун Н.В., Сельский В.К., Дистрянов В.М. и др. Стратиграфическая характеристика мел-палеогеновых отложений первой сверхглубокой скважины в Карпатах - Шевченково-1. Тектоника и стратиграфия. 1980. Вып. 18. С. 72-83.

Maslun N.V., Selskiy V.K., Distryanov V.M. et al., 1980. Stratigraphic characteristics of the Cretaceous-Paleogene deposits of the first super-deep well in the Carpathians - Shevchenkovo-1. Tektonika i stratigrafiya, iss. 18, p. 72-83 (in Russian).

51. Маслун Н.В. Агглютинирующие фораминиферы пограничных эоцен-олигоценовых отложений Карпат. Палеонтол. сб. 1987. № 24. C. $66-70$.
Maslun N.V., 1987. Agglutinated foraminifera of Eocene-Oligocene deposits of Carpathians. Paleontologicheskiy sbornik, № 24, p. 66-70 (in Russian).

52. Маслун Н.В.. Иноземцев Ю.И., Оровецкий Ю.Ю. Нижнекайнозойские отложения Крымского континентального склона Черного моря (результаты 37-го рейса НИС «Академик Вернадский»). Киев, 1989. 36 с. (Препр. / АН УССР. Ин-т геол. наук; 89-13).

Maslun N.V. Inozemtsev Yu.I., Orovetskiy Yu.Yu., 1989. Lower Cenozoic deposits of the Crimean Black Sea continental slope (results of 37 trip NIS «Akademik Vernadskiy»). Kiev, 36 p. (Preprint / Ukrainian Academy of Sciences. Institute of Geological Sciences; 89-13) (in Russian).

53. Маслун Н.В. Детальная стратификация, корреляция и условия образования палеоценовых отложений в нефтегазоносных областях Украины. В кн.: Палеонтологические исследования на Украине. Киев, 1990. С. 101-103.

Maslun N.V., 1990. Detailed stratification, correlation, and conditions of formation of Paleocene deposits of oil and gas regions of Ukraine. In: Paleontological studies in Ukraine. Kiev, p. 101-103 (in Russian).

54. Маслун Н.В., Люльева С.А. Проблемы переходного интервала от мела к палеогену Украины. Проблеми створення шкали геологічного часу докембрію і фанерозою України. (Препр. ІГН НАН України). Киев, 1993. 86 с.

Maslun N.V., Lyuleva S.A., 1993. Problems of the transition range from the Cretaceous to the Paleocene of Ukraine. Problems of Precambrian and Phanerozoic geological time scale of Ukraine. (Preprint IGS of NAS of Ukraine). Kiev, 86 p. (in Russian).

55. Маслун Н.В., Цихоцька Н.Н., Клюшина Г.В. Стратиграфія олігоценових відкладів північно-західного шельфу Чорного моря. Геол. журн. 2004. № 4 (310). C. 16-27.

Maslun N.V., Tsyhotska N.N., Klyushyna G.V., 2004. Stratigraphy of Oligocene sediments of the northwestern Black Sea shelf. Geologichnyy zhurnal, № 4 (310), p. 16-27 (in Ukrainian).

56. Маслун Н.В., Андреєва-Григорович А.С., Іванік М.М. та ін. Біостратиграфічне обґрунтування розчленування кайнозойських відкладів прикерченського шельфу Чорного моря. В кн.: Проблеми палеонтології та біостратиграфії протерозою і фанерозою України: Зб. наук. пр. ІГН НАН України. Київ, 2006. С. 172-179.

Maslun N.V., Andreeva-Gygorovych A.S., Ivanik M.M. et al., 2006. Biostratigraphic justification of Cenozoic sediments differentiation of Prykerchensky shelf of the Black Sea. In: Problems of paleontology and biostratigraphy of Proterozoic and Phanerozoic of Ukraine. Coll. Sci. works of IGS of NAS of Ukraine. Kyiv, p. 172-179 (in Ukrainian). 
57. Мінтузова Л. Г. Особливості стратифікації кайнозою південно-західної частини Керченського півострова. В кн.: Еволюція органічного світу як підгрунтя для вирішення проблем стратиграфії: Зб. наук. пр. ІГН НАН України. Київ, 2002. С. 69-70.

Mintuzova L.G., 2002. Features of Cenozoic stratification of south-western part of Kerch peninsula. In: Organic world evolution as the basis for solving the problems of stratigraphy: Coll. Sci. works of IGS of NAS of Ukraine. Kyiv, p. 69-70.

58. Мінтузова Л. Г., Трофимович Н. А., Яцожинський О. М., Кшановска Т. О. Літобіостратиграфічна характеристика розрізу пошукової свердловини Західно-Бірюча-1 (Азовське море). В кн.: Палеонтологічні дослідження в Україні: Історія, сучасний стан та перспективи: Зб. наук. пр. ІГН НАН України. Київ, 2007. С. 195-199.

Mintuzova L.G., Trofimovich N.A., Yatsozhynsky O.M., Kshanovska T.O., 2007. Lithobiostratigraphic characteristics of section of the search hole Zakhidno-Biruchia-1 (Sea of Azov). In: Paleontological research in Ukraine: History, current state and prospects: Coll. Sci. works of IGS of NAS of Ukraine, Kyiv, p. 195-199.

59. Мінтузова Л.Г. Детальна стратифікація палеоцен-еоценових відкладів Керченського півострова та їх кореляція з прилеглими районами Криму. В кн.: Біостратиграфічні основи побудови стратиграфічних схем фанерозою України: Зб. наук. пр. ІГН НАН України. Київ, 2008. С. 150-158.

Mintuzova L.G., 2008. Detailed stratification of Palaeocene-Eocene sediments of the Kerch Peninsula and their correlation with the surrounding regions of the Crimea. In: Biostratigraphic bases of Phanerozoic stratigraphic schemes creation of Ukraine: Coll. Sci. works of IGS of NAS of Ukraine, Kyiv, p. 150-158 (in Ukrainian).

60. Мінтузова Л. Г. Біофаціальний аналіз палеоценових відкладів Керченського півострова. В кн.: Викопна фауна і флора України: палеоекологічний та стратиграфічний аспекти: Зб. наук. пр. ІГН НАН України. Київ, 2009. С. 212-219.

Mintuzova L.G., 2009. Biofacial analysis of Paleocene deposits of Kerch peninsula. In: Fossil fauna and flora of Ukraine: stratigraphic and paleoecological aspects: Coll. Sci. works of IGS of NAS of Ukraine, Kyiv, p. 212-219.

61. Мінтузова Л.Г. Біостратиграфія палеоценеоценових відкладів Керченського півострова та прилеглих територій за форамініферами: автореф. дис. ... канд. геол. наук. Київ, 2011. 24 с.

Mintuzova L.G., 2011. Biostratigraphy Palaeocene-Eocene sediments of the Kerch Peninsula and surrounding areas by foraminifers: Thesis ... Candidate Geol. Sci. Kyiv, 24 p. (in Ukrainian).

62. Мороз С.А., Соколов И.П., Совяк-Круковский Н.А. Пограничные мел-палеогеновые стратоны в опорных разрезах платформенной
Украины. В кн.: Проблеми створення шкали геологічного часу докембрію і фанерозою України. (Препр. ІГН НАН України). Киев, 1993. 86 с.

Moroz S.A., Sokolov I.P., Sovyak-Krukovskiy N.A., 1993. Boundary Cretaceous-Paleogene stratigraphic units in the reference sections of the platform Ukraine. In: Problems of geological time scale creation of Precambrian and Phanerozoic of Ukraine. (Preprint IGS of NAS of Ukraine). Kiev, 86 p. (in Russian).

63. Мятлюк Е.В. Стратиграфия флишевых осадков Северных Карпат в свете данных фауны фораминифер. Тр. ВНИГРИ. 1950. Вып. 51. С. 225302.

Myatlyuk E.V., 1950. Stratigraphy of flysch sediments of the Northern Carpathians according to foraminifera fauna data. Trudy VNIGRI, iss. 51, p. 225-302 (in Russian).

64. Мятлюк Е.В. Фораминиферы флишевых отложений Восточных Карпат (мел - палеоген). Ленинград: Недра, 1970. 360 с.

Myatlyuk E.V., 1970. Foraminifers of flysch sediments of the Eastern Carpathians (Cretaceous Paleogene). Leningrad: Nedra, 360 p. (in Russian).

65. Найдин Д.П. Датские и монские отложения Крыма. В кн.: Сборник в честь академика Йовчо Смиловича Йовчева. София, 1964. C. 167-184

Naidin D.P., 1964. Danian and Monian deposits of Crimea. In: Collection in honor of academician Yovcho Smilovich Yovchev. Sofia, p. 167-184 (in Russian).

66. Носовский М.Ф., Коненкова И.Д., Богданович Е.М. О границе эоцена и олигоцена на юге Украины. Днепропетровск, 1984. C. 82-88.

Nosovskiy M.F., Konenkov I.D., Bogdanovich E.M., 1984. On the boundary of Eocene and Oligocene in southern Ukraine. Dnepropetrovsk, p. 82-88 (in Russian).

67. Носовский М.Ф., Ярцева М.В. Палеогеновые отложения южного склона Украинского кристаллического массива. В кн.: Палеогеновые отложения юга европейской части СССР. Москва: Изд-во АН СССР, 1960. С. 173-186.

Nosovskiy M.F., Yartseva M.V., 1960. Paleogene deposits of the southern slope of the Ukrainian crystalline massif. In: Paleogene deposits of the south of the European part of USSR. Moscow: Izdatelstvo AN SSSR, p. 173-186 (in Russian).

68. Никитина Ю.П. О киевском и харьковском "ярусах" Скифской платформы. Бюл. Моск. о-ва испытателей природы. Отд. геол. 1963. Т. 38, вып. 1. С. 94-108.

Nikitina Yu.P., 1963. About Kiev and Kharkov «stages» of Scythian Platform. Bulleten Moskovskogo obshchestva ispytateley prirody. Otd. geol., vol. 38, iss. 1, p. 94-108 (in Russian).

69. Обоснование стратиграфических подразделений мезо-кайнозоя Украины по микрофауне / 
под ред. В.Я. Дидковского. Киев: Наук. думка, 1975. 231 c.

Justification of stratigraphic units of the Mesozoic-Cenozoic of Ukraine on microfauna / Ed. V.Ya. Didkovskiy. Kiev: Naukova Dumka, 1975. 231 p. (in Russian).

70. Печенкина А.П. Микропалеонтологическая характеристика нижней части олигоцена Крыма, Причерноморской впадины, Западного и Центрального Предкавказья. В кн.: Стратиграфия и палеогеография кайнозоя газонефтеносных областей юга Советскогго Союза. Москва: Недра, 1971. С. 104-116. (Тр. ВНИИГаз; Вып. 31/39-32/40).

Pechenkina A.P. 1971. Microfossils characteristic of the lower part of the Oligocene of Crimea, Black Sea basin, the Western and Central Pre-Caucasus. In: Stratigraphy and paleogeography of Cenozoic of oil and gas potential areas of the south USSR. Moscow: Nedra, p. 104-116. (Trudy VNIIGAZ; Iss. 31/39-32/40) (in Russian).

71. Пономарьова Л. Форамініфери крейдових відкладів Голятинської структури. В кн.: Палеонтологічні дослідження в Україні: історія, сучасний стан та перспективи: Зб. наук. пр. ІГН НАН України. Київ, 2007. С. 192-194.

Ponomaryova L., 2007. Cretaceous sediments foraminifera of Holyatynska structure. In: Paleontological research in Ukraine: history, current state and prospects: Coll. Sci. works of IGS of NAS of Ukraine. Kyiv, p. 192-194 (in Ukrainian).

72. Рябоконь Т.С. Форамініфери середнього еоцену південного схилу Українського щита: автореф. дис. ... канд. геол.-мінерал. наук. Київ, 1993. $21 \mathrm{c}$.

Riabokon T.S., 1993. Middle Eocene foraminifera southern slope of Ukrainian Shield: Author. Thesis. ... Candidate geol.-mineral. sci. Kyiv, 21 p. (in Ukrainian).

73. Рябоконь Т.С. Про біостратиграфію палеогену Південної України за планктонними форамініферами. Проблеми геології фанерозою України: Матеріали V Всеукр. наук. конф. (8-10 жовтня 2014, Львів). Львів, 2014. С. 101-104.

Riabokon T.S., 2014. Paleogene biostratigraphy of Southern Ukraine on planktonic foraminifera. Problems of geology Phanerozoic Ukraine: Proceedings of the V Ukrainian Sci. conf. (8-10 October 2014, Lviv). Lviv, p. 101-104 (in Ukrainian).

74. Рябоконь T.C. Біостратиграфія палеогенових відкладів Східного Приазов'я за форамініферами. В кн.: Зб. наук. пр. ІГН НАН України. 2013. Т. 6, вип. 1. С. 80-89.

Riabokon T.S., 2013. Biostratigraphy of Paleogene deposits of Eastern Azov by foraminifers. In: Coll. Sci. works of IGS of NAS of Ukraine. Kyiv, vol. 6, iss. 1, p. 80-89 (in Ukrainian).

75. Рябоконь Т.С. Биостратиграфическое значение фораминифер среднего эоцена южной части Украинского щита. В кн.: Сучасні напрямки української геологічної науки: Зб. наук. пр. ІГН НАН України. Київ, 2006. С. 255-276.

Riabokon T.S., 2006. Biostratigraphic value of Middle Eocene foraminifera of the southern part of the Ukrainian Shield. In: Modern trends of Ukrainian geological science: Coll. Sci. works of IGS of NAS of Ukraine, Kyiv, p. 255-276 (in Russian).

76. Рябоконь Т.С. Комплекси планктонних форамініфер олігоцену Південної України. В кн.: Проблеми стратиграфії фанерозою України: Зб. наук. пр. ІГН НАН України. Київ, 2004. С. 128-132.

Riabokon T.S., 2004. Planktonic foraminifera complexes of Oligocene of Southern Ukraine. In: Problems Phanerozoic stratigraphy Ukraine: Coll. Sci. works of IGS of NAS of Ukraine, Kyiv, p. 128-132 (in Ukrainian).

77. Савенко Н.Г. Нові дані про стратиграфічне розчленування палеогенових відкладів південнозахідної частини Дніпровсько-Донецької западини (Кобиляцька площа). Доп. АН УРСР. Сер. Б. 1972. № 4. С. 328-330.

Savenko N.G., 1972. New data on stratigraphic differentiationof Paleocene deposits of the southwestern part of the Dnieper-Donets depression (Kobylyatska area). Dopovidi AN URSR. Ser. B, № 4, p. 328-330 (in Ukrainian).

78. Семененко В.Н. Проблемы миоцен-плиоценовой границы. В кн.: Проблеми створення шкали геологічного часу докембрію і фанерозою України. (Препр. ІГН НАН України). Київ, 1993. 86 с.

Semenenko V.N., 1993. Problems of MiocenePliocene boundary. In: Problems of geologic time scale creation of Precambrian and Phanerozoic of Ukraine. (Preprint of Institute of Geological Sciences of Ukraine). Kyiv, 86 p. (in Russian).

79. Стратиграфическая схема фанерозойских образований Украины для геологических карт нового поколения. Графические приложения. Киев, 1993.

Stratigraphic scheme of the Phanerozoic formations of Ukraine for the new geological maps. Graphic applications. Kiev, 1993 (in Russian).

80. Субботина Н.Н. Верхнеэоценовые лягениды и булиминиды Юга СССР. В кн.: Микрофауна СССР. Ленинград: Гостоптехиздат, 1953. Вып. 6. С.115-283.

Subbotina N.N., 1953. Upper Eocene lagenida and buliminida of South USSR. In: Microfauna USSR. Leningrad: Gostoptekhizdat, iss. 6, p. 115-283 (in Russian).

81. Субботина Н.Н. Глобигериниды, ханткениниды и глобороталииды. В кн.: Ископаемые фораминиферы СССР. Москва: Гостоптехиздат, 1953. 296 с. (Тр. ВНИГРИ. Н.С.; Вып. 76).

Subbotina N.N., 1953. Globigerinida, hantkeninida and globorotaliida. In: Fossil foraminifera of USSR. Moscow: Gostoptekhizdat, 296 p. (Trudy VNIGRI; Iss. 76) (in Russian). 
82. Субботина Н.Н. Микрофаунистическая характеристика верхнеэоценовых отложений окрестностей г. Бахчисарая как основа для сопоставления с разрезом в окрестностях г. Будапешта. Ann. Inst. Geol. publ. Hung. 1971. Vol. UV, fase. 4. Pars. II. P. 94-101.

Subbotina N.N., 1971. Microfauna characteristics of Upper Eocene deposits near Bakhchisarai as a basis for comparison with a section of Budapest. Ann. Inst. Geol. publ. Hung., vol. UV, fase. 4, pars. II, p. 94-101 (in Russian).

83. Субботина Н.Н., Пишванова Л.С., Иванова Л.В. Стратиграфия олигоценовых и миоценовых отложений Предкарпатья по фораминиферам. В кн.: Микрофауна СССР. Сб. ХХІ. Тр. ВНИГРИ, 1960. Вып. 153. С. 5-156.

Subbotina N.N., Pishvanova L.S., Ivanova L.V. Stratigraphy of Oligocene and Miocene deposits of Precarpathians on foraminifera. In: Microfauna USSR. Coll. XXI. Works VNIGRI, 1960, iss.153, p. 5-156 (in Russian)

84. Субботина Н.Н. Пелагические фораминиферы палеогеновых отложений юга СССР. В кн.: Палеогеновые отложения юга европейской части СССР. Москва: Изд-во АН СССР. 1960. С. 24-38.

Subbotina N.N., 1960. Pelagic foraminifera of Paleogene deposits of south of the USSR. In: Paleogene deposits of south of the European part of the USSR. Moscow: Izdatelstvo AN SSSR. p. 24-38 (in Russian).

85. Тер-Григорьянц Л.С. Майкопские отложение Центрального Предкавказья (стратиграфия, палеогеография, фораминифери): Автореф. дис. ...канд. геол.-минерал. наук, Москва, 1969. 25 с.

Ter-Grigor'yants L.S., 1969. Maikop deposits of central Caucasus (stratigraphy, paleogeography, foraminifera): Author. Thesis. ... Candidate geol.-mineral. sci., Moscow. 25 p.

86. Трофимович Н.А., Мінтузова Л.Г., Кшановська Т.О. та ін. Літобіостратиграфічна характеристика розрізу пошукової свердловини Західно-Бірюча-1 (Азовське море). В кн.: Палеонтологічні дослідження в Україні: історія, сучасний стан та перспективи: Зб. наук. пр. ІГН НАН України. Київ, 2007 С. 195-199.

Trofimovich N.A., Mintuzova L.G., Kshanovska T.O. et al., 2007. Lithobiostratigraphic characteristics of the section of search hole Zakhidno-Biryucha-1 (Azov Sea). In: Paleontological research in Ukraine: history, current state and prospects: Coll. Sci. works of IGS of NAS of Ukraine. Kyiv, p. 195-199 (in Ukrainian).

87. Тутковский П.А. Фораминиферы из третичных и меловых отложений Киева. Статья 1. ЗКОЕ, т. VIII,вып. 2, с. 345-360, табл. III-VII. Реф.: Bull. Soc., Belg. Geol., Hydrol. Et Paleont., 1887, t, I, proc, verb., p. 195).

Tutkovsky P.A., 1887. Foraminifera of the Tertiary and Cretaceous sediments of Kiev. Article 1. 3KOE, vol. VIII, №. 2, p. 345-360, tab. III-VII. Ref.: Bull. Soc., Belg. Geol., Hydrol. Et Paleont., t, I, proc, verb., p. 195 (in Russian).

88. Тутковский П.А. Фораминиферы из Керченского неогена. ЗКОЕ, т. ХІ, вып. 1, прот. засед. за 1889 г., с. LXXIII и XCIII.

Tutkovsky P.A., 1889. Foraminifera from Kerch Neogene. 3KOE, vol. XI, № 1, p. LXXIII and XCIII (in Russian).

89. Тутковський П.А. Копальні мікрофауни України, їх геологічна вага і методи їх дослідження. Київ. Вид-во АН УРСР, 1925. Ч. І. С. 1-4. Табл. 1-42.

Tutkovsky P.A., 1925. Mines of microfauna of Ukraine, their geological weight and their research methods. Kyiv. Vydavnytstvo AN URSR, vol. I, p. 1-4, tab. 1-42 (in Ukrainian).

90. Улановская T.E. Кумский горизонт среднего эоцена в южных морях европейской части бывшего СССР. Геология морей и океанов: Тез. докл. XV Междунар. шк. мор. геологии. Т. 2. Москва, 2003. С. 283-284.

Ulanovskaya T.E., 2003. Kuma horizon of the Middle Eocene in the southern seas of the European part of the former USSR. Geology of the oceans and seas: Thes. rep. XV Intern. sc. sea geology, vol. 2. Moscow, p. 283-284 (in Russian).

91. Улановская Т.Е., Неваленный Ю.В. Верхний эоцен и его граница с олигоценом в АзовоЧерноморском регионе. Изв. вузов. Геология и разведка. 2000. № 5. С. 3-12.

Ulanovskaya T.E., Nevalenny Yu.V., 2000. Upper Eocene and Oligocene border in the Azov-Black Sea region. Izvestiya vuzov. Geologiya i razvedka, № 5, p. 3-12 (in Russian).

92. Фурсенко А.В., Фурсенко К.Б. Фораминиферы верхнего эоцена Белоруссии и их стратиграфическое значение. В кн.: Палеонтология и стратиграфия БССР. Сб. 3. Минск, 1961. С. 246-347.

Fursenko A.V., Fursenko K.B., 1961. Upper Eocene foraminifera of Belarus and their stratigraphic significance. In: Paleontology and stratigraphy of BSSR. Coll. 3. Minsk, p. 246-347 (in Russian).

93. Шнюков Е.Ф., Маслун Н.В., Иноземцев Ю.И., Оровецкий Ю.Ю. Новые данные о геологическом строении континентального склона Южного Крыма. Геол. журн. 1990. № 3 (252). С. 88-98.

Shnyukov E.F., Maslun N.V., Inozemtsev Yu.I., Orovetskiy Yu.Yu., 1990. New data on the geological structure of the continental slope of the Southern Crimea. Geologicheskiy zhurnal, № 3 (252), p. 88-98 (in Russian).

94. Шуцкая Е.К. Пограничные слои эоцена и олигоцена Бахчисарайского района и описание характерных аномалинид. В кн.: Материалы по геологии и нефтегазоносности юга СССР. Москва, 1963. С. 174-197. (Тр. ВНИГНИ; Вып. 38).

Shutskaya E.K., 1963. Boundary Eocene and Oligocene layers of Bakhchysarai area and a descrip- 
tion of specific anomalinidas. In: Materials on geology and oil and gas south of the USSR. Moscow, p. 174197. (Trudy VNIGNI; Iss. 38) (in Russian).

95. Шуцкая Е.К. Стратиграфия, фораминиферы и палеогеография нижнего палеогена Крыма, Предкавказья и западной части Средней Азии. Москва: Недра, 1970. 255 с.

Shutskaya E.K., 1970. Stratigraphy, paleogeography and foraminifera of Lower Paleogene Crimea, the Caucasus and the western part of Central Asia. Moscow: Nedra, 255 p. (in Russian).

96. Ярцева М.В. О верхнеэоценовых милиолидах Никопольского района и среде их обитания. Тр. Ин-та геол. наук АН Украины. Сер. Стратиграфия и палеонтология. 1951. Вып. 6. С. 42-67.

Yartseva M.V., 1951. Upper Eocene miliolida of Nikopol district and their habitats. Trudy IGN AN Ukrainy. Ser. Stratigrafiya i Paleontologiya, iss. 6, p. 42-67 (in Russian).

97. Ярцева М.В. До стратиграфії олігоценових відкладів південно-східного схилу Українського кристалічного щита (за фауною фораміфніфер). Геол. журн. 1959. Т. 19, вип. 3 (66). С. 25-36.

Yartseva M.V., 1959. To Stratigraphy of Oligocene sediments of the southeastern slope of the Ukrainian Shield (by foramifnifera fauna). Geologichnyy zhurnal, vol. 19, iss. 3 (66), p. 25-36 (in Ukrainian).

98. Ярцева М.В. Характеристика комплексів бентосних форамініфер дату та палеоцену стратотипових розрізів Бахчисарайського району. Тектоніка і стратиграфія. 1973. Вип. 6. С. 33-40.

Yartseva M.V., 1973. Characterization of benthic foraminifera complex of Danian and Paleocene of stratotype sections of Bakhchisaray region. Tectonika i stratigrafiya, iss. 6, p. 33-40 (in Ukrainian).

99. Ярцева М.В., Краева Е.Я. Планктонные фораминиферы нижнего палеоцена ДнепровскоДонецкой впадины. Палеонтол. сб. 1977. № 14. C. 24-33.

Yartseva M.V., Krayeva E. Ya., 1977. Lower Paleocene planktonic foraminifera of the Dnieper-Donets depression. Paleontologicheskiy sbornik, № 14, p. 24-33 (in Russian).

100. Ярцева М.В., Краева Е.Я. Новые данные о возрасте и стратиграфических аналогах эоценовых отложений южного склона Украинского щита. Тектоника и стратиграфия. 1983. № 4. С. 79-87.

Yartseva M.V., Krayeva E. Ya., 1983. New data on the age and stratigraphic equivalents of Eocene sediments of the southern slope of the Ukrainian Shield. Tectonika i stratigrafiya, № 4, p. 79-87 (in Russian).

101. Gozhik P.F., Maslun N.V., Ivanik M.M. et al. Stratigraphic model of the Mesozoic and Cenozoic of the western Black Sea basin. Геология и полез. ископаемые Мирового океана. 2008. № 1. С. 55-69.

Gozhik P.F., Maslun N.V., Ivanik M.M. et al., 2008. Stratigraphic model of the Mesozoic and Cenozoic of the western Black Sea basin. Geologiya $i$ poleznye iskopayemye Mirovogo okeana, № 1, p. 5569 (in English).

102. Gozhyk P.F., Maslun N.V., Ivanik Ye.M., Kliushyna G.V. Stratigraphy of Paleogene, Neogene and Quaternary deposits in the Black Sea oil-gas province of Ukraine. Стратиграфия и седиментология нефтегазоносных бассейнов. 2011. № 2. C. 15-31.

Gozhyk P.F., Maslun N.V., Ivanik Ye.M., Kliushyna G.V., 2011. Stratigraphy of Paleogene, Neogene and Quaternary deposits in the Black Sea oil-gas province of Ukraine. Stratihrafiya i sedimentologiya neftegazonosnykh basseynov, № 2, p. 1531 (in English).

103. Olszewska B. Biostratygrafla serii menilitowo-kros'nieriskiej w okolioy Przemysla. Biul. Inst. Geol. 1984. Vol. 23, № 340. S. 45-87.

Olszewska B., 1984. Biostratygrafla serii menilitowo-kros'nieriskiej w okolioy Przemysla. Biul. Inst. Geol., vol. 23, № 340, S. 45-87 (in Polish).

104. Semenenko V.N., Andreyeva-Grigorovich A.S., Maslun N.V., Luljeva S.A. The direct correlation of the Neogene of the Eastern Paratethys and Tethys. AAPG European Region Annual Conference. Exploration in the Black Sea and Caspian Regions, October 17-19 2010, Kiev, Ukraine. Режим доступу до журн.: http://www.searchanddiscoverv.net/

Semenenko V.N., Andreyeva-Grigorovich A.S., Maslun N.V., Luljeva S.A. The direct correlation of the Neogene of the Eastern Paratethys and Tethys. AAPG European Region Annual Conference. Exploration in the Black Sea and Caspian Regions, October 17-19 2010, Kiev, Ukraine. Available at: http://www. searchanddiscoverv.net/ (in English).

105. Waga D.D., Andreeva-Grigorovich A.S., Maslun N.V. Calcareous nannofossil biostratigraphy of the Paleocene sediments of the Odessa Gas Field (NW Black Sea): 12th Meeting of the International Nannoplankton Association, Lyon, 2008. Geobios. 2010. Vol. 43, iss. 1. P. 33-43.

Waga D.D., Andreeva-Grigorovich A.S., Maslun N.V., 2010. Calcareous nannofossil biostratigraphy of the Paleocene sediments of the Odessa Gas Field (NW Black Sea): 12th Meeting of the International Nannoplankton Association, Lyon, 2008. Geobios, vol. 43, iss. 1, p. 33-43 (in English).

Received April 16, 2015 